\title{
Outcomes of Endovascular Treatment of Intracranial Aneurysms at Bifurcation Sites
}

\author{
Ahmed Saied ${ }^{1,2}$, Mohamed Gomaa1, Talal Amer ${ }^{3}$, Mohamed Saad1, Demetrius Lopes ${ }^{2}$ \\ ${ }^{1}$ Department of Neurology, Mansoura University, Mansoura, Egypt \\ ${ }^{2}$ Department of Neurosurgery, Rush University Medical Center, Chicago, USA \\ ${ }^{3}$ Department of Radiology, Mansoura University, Mansoura, Egypt \\ Email: *ahmed.effat222@gmail.com
}

How to cite this paper: Saied, A., Gomaa, M., Amer, T., Saad, M. and Lopes, D. (2018) Outcomes of Endovascular Treatment of Intracranial Aneurysms at Bifurcation Site. World Journal of Neuroscience, $\mathbf{8}$, 432-443.

https://doi.org/10.4236/wjns.2018.84034

Received: September 27, 2018

Accepted: October 29, 2018

Published: November 1, 2018

Copyright (C) 2018 by authors and Scientific Research Publishing Inc. This work is licensed under the Creative Commons Attribution International License (CC BY 4.0).

http://creativecommons.org/licenses/by/4.0/

\section{Open Access}

\begin{abstract}
Background and Purpose: Endovascular coiling is widely used for treatment of both ruptured and unruptured aneurysms. Intracranial bifurcation aneurysms were classically considered unsuitable for endovascular treatment because of the risk of coil protrusion into the parent vessel. The introduction stent assisted coiling has allowed the bifurcation aneurysms to be endovascularly treated. The present study aims to evaluate the efficacy of the endovascular treatment of the intracranial bifurcation aneurysms. Methods: This study was conducted on 76 patients with radiologically documented intracranial aneurysms at bifurcation sites either ruptured (12 aneurysms) or unruptured (64 aneurysms). Endovascular coiling of intracranial aneurysms was done for all patients in our study aided in some with single or Y-configuration stenting. The radiological outcome was assessed immediately postoperative, and at follow-up at 6 and 12 month with grading of the angiograms on the basis of modified 3-point Raymond scale. Results: In terms of the Raymond grading (RG), the initial angiographic outcome was complete occlusion (RG1) in 45 aneurysms (59.2\%), neck remnant (RG2) in 20 aneurysms (26.3\%), and body filling (RG3) in 11 aneurysms (14.5\%), while the final angiographic outcome at 1 year was RG1 in 55 aneurysms (72.4\%), RG2 in 13 aneurysms (17.1\%), and RG3 in 8 aneurysms (10.5\%). Eleven aneurysms (14.5\%) showed recanalization. The aneurysm size and the neck width were the statistically significant factors affecting the initial $R G(P=0.0005,0.001$ respectively), final $R G(P=0.015$, 0.012 respectively), and the recanalization rate $(\mathrm{P}=0.012,0.01$ respectively). Conclusions: Endovascular treatment of intracranial aneurysms at bifurcation sites is safe and effective. Stent assisted coiling (SAC) has enabled us to offer a safe and effective endovascular treatment for bifurcation aneurysms by preventing coils herniation. Smaller aneurysm size and neck size are indicators of complete occlusion and lower recanalization rate.
\end{abstract}




\section{Keywords}

Bifurcation Aneurysm, Stent Assisted Coiling, Recanalization, Simple Coiling

\section{Introduction}

Intracranial aneurysm tends to occur at regions of sharp vessel curvature, and bifurcations such as the basilar bifurcation, the internal carotid artery (ICA) bifurcation, the middle cerebral artery (MCA) bifurcation, and the anterior communicating artery. The reason for this is unknown, but the heterogeneous distribution suggests the presence of local contributing factors such as high wall shear stress, turbulence, and other hemodynamic forces implicated in its pathogenesis [1].

Most intracranial aneurysms are clinically silent until rupture, which is unpredictable and sometimes associated with subarachnoid hemorrhage, intraparenchymal hemorrhage, and an intraventricular hemorrhage [2].

Decision for treatment of intracranial aneurysm is based on clinical and anatomic factors such as the patient's age, family history of intracranial aneurysm, symptomatic aneurysms, aneurysm size, aneurysm location, and associated conditions like autosomal dominant polycystic kidney disease (ADPKD) [2]. Endovascular coiling is considered the first line treatment of ruptured and unruptured aneurysms especially after the publication of International Subarachnoid Aneurysm Trial (ISAT) results [3].

Intracranial bifurcation aneurysms were previously considered unsuitable for endovascular treatment because of the risk of coil protrusion into the parent vessel and were typically managed by surgical clipping. Recent advancements in endovascular devices and techniques have placed such aneurysms within the range of endovascular therapy. The introduction of stent assisted coiling has allowed the bifurcation aneurysms to be endovascularly treated [4].

Follow-up imaging after endovascular management of intracranial aneurysm by digital subtraction angiography (DSA) or magnetic resonance angiography (MRA) is crucial. The most important reason for this follow-up is the fact that recanalization after coiling has a high frequency; the issue that exposes the patient to the risk of recurrent subarachnoid hemorrhage (SAH) [5]. Previous studies reported the immediate and follow-up angiographic results without attention to recanalization and the factors that may be responsible for failure of treatment at follow-up after initially successful outcomes.

Aim of the study: The aim of present study is to evaluate the efficacy of the endovascular treatment of the intracranial bifurcation aneurysms, and to analyze the factors that may affect the angiographic outcomes.

\section{Patients and Methods}

This study was conducted in the neurosurgery department at RUSH medical 
center, Chicago. IL, from December 2016 to May 2018. The inclusion criteria were:

1) Patients with radiologically documented ruptured or unruptured intracranial bifurcation aneurysms.

2) Patients physically fit for the endovascular treatment procedures.

It was conducted on76casesof bifurcation sites intracranial aneurysms either ruptured (12 aneurysms) or unruptured (64 aneurysms) after obtaining written informed consent from all patients. All patients are subjected to detailed history taking, physical examination, laboratory investigations. All the aneurysms were radiologically documented by conventional digital subtraction angiography (DSA).

Endovascular coiling of intracranial aneurysms was done for all patients in our study aided in some cases with single or Y-configuration stenting. Immediate postoperative angiographic runs were obtained in working projections to determine the angiographic end result. Patients were subjected to angiographic follow-up (DSA or MRA) at 6 and 12 month following the treatment. The degree of aneurysm occlusion was graded immediately after treatment and at follow up using modified Raymond grading, where grade 1, complete occlusion; grade 2, residual neck; and grade 3, aneurysm body filling [6]. At follow-up, an aneurysm was considered recanalized if any further filling of the aneurysm neck or sac was observed compared with the initial treatment findings [7].

\subsection{Analysis of Certain Factors in Relation to the Angiographic Outcomes}

Certain factors were analyzed in relation to angiographic outcomes like the pretreatment angiographic data and the treatment related factors. Pretreatment geometric data included aneurysm site, aneurysm size, neck width, dome-neck ratio, and aspect ratio. Treatment related factors included treatment modality, stent type, initial RG, and the packing density ( $\leq 24 \%$ or $>24 \%$ ). Packing density was available for only 51 aneurysms using AngioSuite software system (Cascade Medical, Knoxville, TN, USA).

\subsection{Statistical Analysis}

Sample size was calculated. Data were statistically analyzed using SPSS 21 (IBM Corp. Armonk, New York). Statistical analysis was done for comparing variables between the groups using Mann-Whitney nonparametric test for numerical variables and Fisher's exact test for categorical variables. P value $\leq 0.05$ was considered to be statistically significant. Multivariable logistic regression was performed on candidate predictor variables to identify variables independently associated with occlusion after adjustment for potential confounders.

\section{Results}

The current study was conducted on 76 radiologically documented aneurysms both ruptured and unruptured at different bifurcation sites. 


\section{1) Demographic data:}

In the current study, 29 patients were males $(38.2 \%)$ and 47 were females (61.8\%) with male-to-female ratio of 1:1.6. The patients' age ranged from 31 to 88 years, with a mean of 61 years $( \pm 12.4)$. Regarding male patients the mean age was 58.4 years $( \pm 11.8)$, whereas the mean age of the female patients was 62.7 years $( \pm 12.3)$. Out of the 76 patients included in the study 34 patients $(44.7 \%)$ have no special habits, 30 patients (39.5\%) were both cigarette smokers and alcoholics, 12patients (15.8\%) were cigarette smokers only. The frequency of risk factors among the studied groups showed that hypertension was the commonest risk factor. Fifty four patients (71.1\%) were hypertensive, 26 patients $(34.2 \%)$ had dyslipidemia, and 5 (7.4\%) patients had family history of aneurysms.

\section{2) Clinical data:}

Out of our study group, only 12 patients (16\%) presented with SAH due to aneurysmal rupture. Most of the patients (31 patients, about $41 \%$ ) presented by headache, only 4 patients (5\%) presented by loss of consciousness, while the remaining (29 patients, about 38.2\%) were incidentally discovered.

\section{3) Pretreatment anatomical and geometric data:}

The bifurcation aneurysm sites were distributed as follows: 30 (39.5\%) in the basilar tip, 20 (26.33\%) in the ICA terminus, 15 (19.7\%) in the AcomA, and 11 (14.5\%) in the MCA bifurcation. The median aneurysm size was $5 \mathrm{~mm}$ (range $1.4-17.4 \mathrm{~mm}$ ), the mean neck width was $4.13 \pm 1.64$ (range $1.5-9 \mathrm{~mm}$ ), dome neck ratio was $1.4 \pm 0.6$ (range $0-4$ ), and aspect ratio was $1.45 \pm 0.58$ (range 0.5 - 3.7).

\section{4) Treatment related factors:}

Fifty three patients $(69.7 \%)$ were treated by single SAC, 15 patients $(19.7 \%)$ were treated by simple coiling, and 8 patients (10.5\%) were treated by Y-stenting. Stents used were 39 Neuroform EZ (Stryker, Fremont, CA, USA), 9 Enterprise (Codman Neurovascular, Raynham, MA, USA), and 13 LVIS Jr. (Microvention, Tustin, CA, USA).

\section{5) Treatment outcomes:}

In terms of the RG, the initial angiographic outcome was complete occlusion (RG1) in 45 aneurysms (59.2\%), neck remnant (RG2) in 20 aneurysms (26.3\%), and body filling (RG3) in 11 aneurysms (14.5\%). The 6 months' angiographic outcome was RG1 in 58 aneurysms (76.3\%), RG2 in 13 aneurysms (17.1), and RG3 in 5 aneurysms (6.6), while the final angiographic outcome at 12 months' follow-up was RG1 in 55 aneurysms (72.4\%), RG2 in 13 aneurysms (17.1\%), and RG3 in 8 aneurysms (10.5\%) (Table 1, Table 2). Eleven aneurysms (14.5\%) showed recanalization (Table 3). There were no periprocedural complications or mortalities. There were no thromboembolic or hemorrhagic complications during follow-up period. In stent stenosis was found in one case at 6 months' follow-up.

Analysis of the factors affecting the angiographic outcome showed that the aneurysm size and the neck width were the statistically significant factors affecting 
Table 1. Statistical analysis for individual factors in relation to the initial RG.

\begin{tabular}{|c|c|c|c|c|}
\hline \multicolumn{5}{|c|}{ Demographic and clinical data } \\
\hline & \multicolumn{3}{|c|}{ Initial RG } & \\
\hline & 1 & 2 & 3 & \\
\hline & $\mathrm{N} \%$ & N\% & $\mathrm{N} \%$ & \\
\hline & $45(59.2)$ & $20(26.3)$ & $11(14.5)$ & $76(100)$ \\
\hline \multicolumn{5}{|l|}{ Age (years) } \\
\hline Mean $\pm S D$ & $61.8 \pm 11.6$ & $61.5 \pm 13.7$ & $57.4 \pm 12.1$ & $\mathrm{P}=0.56$ \\
\hline Gender & & & & \multirow{3}{*}{$\mathrm{P}=0.72$} \\
\hline Male & $18(62.1)$ & $8(27.6)$ & $3(10.3)$ & \\
\hline Female & $27(57.4)$ & $12(25.5)$ & $8(17.0)$ & \\
\hline Hypertension & $33(61.1$ & $13(24.1)$ & $8(14.8)$ & $\mathrm{P}=0.78$ \\
\hline Dyslipidemia & $16(61.5)$ & $7(26.9)$ & $3(11.5)$ & $\mathrm{P}=0.85$ \\
\hline Smoking & $25(59.5)$ & $10(23.8)$ & $7(16.7)$ & $\mathrm{P}=0.81$ \\
\hline Alcohol drinking & $15(50.0)$ & $9(30.0)$ & $6(20.0)$ & $\mathrm{P}=0.37$ \\
\hline $\begin{array}{l}\text { Clinical presentation } \\
\text { - Unruptured } \\
\text { - Ruptured }\end{array}$ & $\begin{array}{c}38(59.5) \\
7(58.3)\end{array}$ & $\begin{array}{c}17(26.5) \\
3(25.0)\end{array}$ & $\begin{array}{l}9(14.0) \\
2(16.7)\end{array}$ & $\mathrm{P}=0.62$ \\
\hline \multicolumn{5}{|c|}{ Pretreatment geometric data } \\
\hline $\begin{array}{ll} & \text { Site } \\
\text { - } & \text { Basilar } \\
\text { - } & \text { Carotid } \\
\text { - } & \text { ACOM } \\
\text { - } & \text { MCA }\end{array}$ & $\begin{array}{c}19(63.3) \\
11(55.0) \\
10(66.7) \\
5(45.5)\end{array}$ & $\begin{array}{l}8(26.7) \\
7(35.0) \\
2(13.3) \\
3(27.3)\end{array}$ & $\begin{array}{l}3(10.0) \\
2(10.0) \\
3(20.0) \\
3(27.3)\end{array}$ & $\mathrm{P}=0.64$ \\
\hline $\begin{array}{l}\text { Aneurysm size } \\
\text { Mean } \pm \text { SD }\end{array}$ & $4.5 \pm 2.66$ & $9.6 \pm 3.76$ & $5.61 \pm 3.36$ & $\begin{array}{c}\mathrm{F}=8.55 \\
\mathrm{P}=0.0005^{*}\end{array}$ \\
\hline $\begin{array}{l}\text { Neck width } \\
\text { Mean } \pm \text { SD }\end{array}$ & $3.13 \pm 0.88$ & $5.22 \pm 1.9$ & $3.90 \pm 1.4$ & $\begin{array}{c}\mathrm{F}=8.13 \\
\mathrm{P}=0.001^{\star}\end{array}$ \\
\hline $\begin{array}{l}\text { Aspect ratio } \\
\text { Mean } \pm \text { SD }\end{array}$ & $1.47 \pm 0.54$ & $1.35 \pm 0.49$ & $1.56 \pm 0.88$ & $\begin{array}{l}F=0.55 \\
P=0.58\end{array}$ \\
\hline $\begin{array}{l}\text { Dome neck ratio } \\
\text { Mean } \pm \text { SD }\end{array}$ & $1.34 \pm 0.51$ & $1.4 \pm 0.62$ & $1.75 \pm 0.89$ & $\begin{array}{l}\mathrm{F}=2.05 \\
\mathrm{P}=0.14\end{array}$ \\
\hline \multicolumn{5}{|c|}{ Treatment related factors } \\
\hline $\begin{array}{l}\text { Treatment modality } \\
\text { - Simple coiling } \\
\text { - Single SAC } \\
\text { - Y-stenting }\end{array}$ & $\begin{array}{c}10(66.7) \\
32(60.4) \\
3(37.5)\end{array}$ & $\begin{array}{c}3(20.0) \\
13(24.5) \\
4(50.0)\end{array}$ & $\begin{array}{l}2(13.3) \\
8(15.1) \\
1(12.5)\end{array}$ & $\begin{array}{c}\mathrm{MC} \\
\mathrm{P}=0.61\end{array}$ \\
\hline $\begin{array}{l}\text { Stent used } \\
\text { - Neuroform } \\
\text { - Enterprise } \\
\text { - Elvis }\end{array}$ & $\begin{array}{l}22(61.3) \\
6(66.7) \\
7(53.8)\end{array}$ & $\begin{array}{l}12(29) \\
1(11.1) \\
3(23.1)\end{array}$ & $\begin{array}{l}5(9.7) \\
2(22.2) \\
3(23.1)\end{array}$ & $\begin{array}{c}\mathrm{MC} \\
\mathrm{P}=0.67\end{array}$ \\
\hline
\end{tabular}

Table 2. Statistical analysis for individual factors in relation to the final RG.

\begin{tabular}{ccc}
\hline \multicolumn{3}{c}{ Demographic and clinical data } \\
\hline \multicolumn{3}{c}{ Final RG } \\
\hline N (\%) & N (\%) & N (\%) \\
\hline
\end{tabular}




\section{Continued}

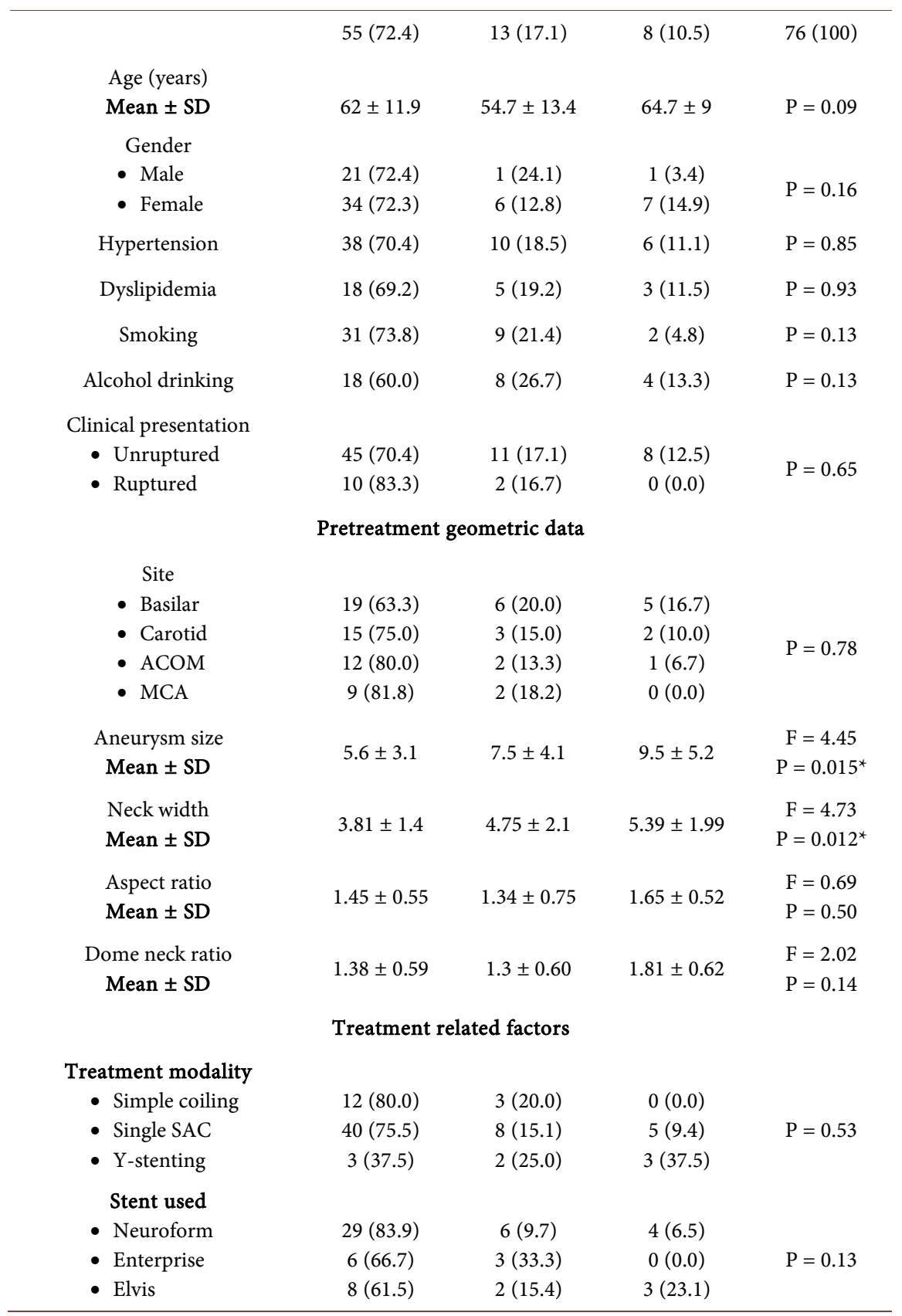

the initial RG $(\mathrm{P}=0.0005,0.001$ respectively $)$, final $R G(P=0.015,0.012$ respectively), and the recanalization rate $(\mathrm{P}=0.012,0.01$ respectively) (Tables 1-3).

\section{Discussion}

The present study consisted of series of 76 aneurysms at 4 different bifurcation sites (basilar tip, ICA terminus, MCA bifurcation, and AcomA) treated by different endovascular modalities. Clinical and angiographic data were collected. Aneurysm occlusion after treatment was categorized according to modified Raymond classification. At follow-up, an aneurysm was considered recanalized 
Table 3. Statistical analysis for individual factors in relation to the recanalization rate.

\begin{tabular}{|c|c|c|c|}
\hline \multicolumn{4}{|c|}{ Demographic and clinical data } \\
\hline & \multicolumn{2}{|c|}{ Recanalization } & \\
\hline & No & Yes & \\
\hline & $65(85.5)$ & $11(14.5)$ & $76(100)$ \\
\hline \multicolumn{4}{|l|}{ Age (years) } \\
\hline Mean \pm SD & $60.9 \pm 12.8$ & $62.1 \pm 7.9$ & $\mathrm{P}=0.77$ \\
\hline $\begin{array}{l}\text { Gender } \\
\text { - Male } \\
\text { - Female }\end{array}$ & $\begin{array}{l}26(89.7) \\
39(83.0)\end{array}$ & $\begin{array}{l}3(10.3) \\
8(17.0)\end{array}$ & $\mathrm{P}=0.72$ \\
\hline Hypertension & $45(83.3)$ & $9(16.7)$ & $\mathrm{P}=0.39$ \\
\hline Dyslipidemia & $22(84.6)$ & $4(15.4)$ & $\mathrm{P}=0.89$ \\
\hline Smoking & $37(88.1)$ & $5(11.9)$ & $\mathrm{P}=0.48$ \\
\hline Alcohol drinking & $24(80.0)$ & $6(20.0)$ & $\mathrm{P}=0.27$ \\
\hline $\begin{array}{l}\text { Clinical presentation } \\
\text { - Unruptured } \\
\text { - Ruptured }\end{array}$ & $\begin{array}{l}54(84.4) \\
11(91.7)\end{array}$ & $\begin{array}{c}10(15.6) \\
1(8.3)\end{array}$ & $P=0.73$ \\
\hline \multicolumn{4}{|c|}{ Pretreatment geometric data } \\
\hline $\begin{array}{l}\text { Site } \\
\text { - Basilar } \\
\text { - Carotid } \\
\text { - ACOM } \\
\text { - MCA }\end{array}$ & $\begin{array}{l}23(76.7) \\
17(85.0) \\
14(93.3) \\
11(100)\end{array}$ & $\begin{array}{l}7(233) \\
3(15.0) \\
1(6.7) \\
0(0.0)\end{array}$ & $\mathrm{P}=0.22$ \\
\hline $\begin{array}{c}\text { Aneurysm size } \\
\text { Mean } \pm \text { SD }\end{array}$ & $5.9 \pm 3.4$ & $8.8 \pm 4.9$ & $\begin{aligned} \mathrm{t} & =-2.31 \\
\mathrm{P} & =0.012^{\star}\end{aligned}$ \\
\hline $\begin{array}{l}\text { Neck width } \\
\text { Mean } \pm \text { SD }\end{array}$ & $3.9 \pm 1.54$ & $5.30 \pm 1.81$ & $\begin{array}{l}t=-0.29 \\
P=0.01^{*}\end{array}$ \\
\hline $\begin{array}{l}\text { Aspect ratio } \\
\text { Mean } \pm \text { SD }\end{array}$ & $1.40 \pm 0.54$ & $1.74 \pm 0.78$ & $\begin{array}{c}\mathrm{t}=-1.83 \\
\mathrm{P}=0.07\end{array}$ \\
\hline $\begin{array}{l}\text { Dome neck ratio } \\
\text { Mean } \pm \text { SD }\end{array}$ & $1.36 \pm 0.60$ & $1.71 \pm 0.58$ & $\begin{array}{l}\mathrm{t}=-1.82 \\
\mathrm{P}=0.07\end{array}$ \\
\hline \multicolumn{4}{|c|}{ Treatment related factors } \\
\hline $\begin{array}{l}\text { Treatment modality } \\
\text { - Simple coiling } \\
\text { - Single SAC } \\
\text { - Y-stenting }\end{array}$ & $\begin{array}{c}14(93.3) \\
46(86.8) \\
5(62.5)\end{array}$ & $\begin{array}{r}1(6.7) \\
7(13.2) \\
3(37.5)\end{array}$ & $\mathrm{P}=0.11$ \\
\hline $\begin{array}{l}\text { Initial RG } \\
\text { - Complete occlusion } \\
\text { - Residual neck } \\
\text { - Body filling }\end{array}$ & $\begin{array}{c}\mathrm{N}(\%) \\
39(60.0) \\
16(24.6) \\
10(15.4)\end{array}$ & $\begin{array}{l}\mathrm{N}(\%) \\
6(54.6) \\
4(36.4) \\
1(9.0)\end{array}$ & $\mathrm{P}=0.57$ \\
\hline $\begin{array}{l}\text { Packing density } \\
\text { - } \leq 24 \\
\text { - }>24\end{array}$ & $\begin{array}{c}\mathrm{N}=42 \\
26(61.9) \\
16(38.1)\end{array}$ & $\begin{array}{c}\mathrm{N}=9 \\
3(33.3) \\
6(66.7)\end{array}$ & $P=0.39$ \\
\hline $\begin{array}{l}\text { Stent used } \\
\text { - Neuroform } \\
\text { - Enterprise } \\
\text { - Elvis }\end{array}$ & $\begin{array}{c}33(90.3) \\
8(88.9) \\
10(76.9)\end{array}$ & $\begin{array}{c}6(9.7) \\
1(11.1) \\
3(23.1)\end{array}$ & $\mathrm{P}=0.55$ \\
\hline
\end{tabular}

if any further filling of the aneurysm neck or sac was observed compared with the initial treatment findings [7]. 
About $70 \%$ of the patients were treated by single SAC, $19.7 \%$ were treated by simple coiling, and $10.5 \%$ were treated by $\mathrm{Y}$-stenting. Stent-assisted coiling (SAC) of bifurcation aneurysms has expanded the spectrum of aneurysms amenable to endovascular therapy by providing neck coverage while preserving the involved vessels from coil prolapsed [8]. Y-stenting is usually reserved to the cases were the neck is centered on the bifurcation, as it will be difficult to protect 2 bifurcation branches with a single device. A scoring system was proposed to assist on the selection of Y-stenting to treat bifurcation site aneurysms [9].

In terms of the percentage of complete occlusions, the initial and follow up angiographic results are in range to the majority of results from previously published endovascular series, where complete occlusion has been achieved initially in $26 \%-76 \%$ of the treated aneurysms and in follow-up in $35 \%-86 \%$ (Table 4 ).

Table 4. Summary of initial and follow-up angiographic results of endovascular series.

\begin{tabular}{|c|c|c|c|c|c|c|c|c|}
\hline \multirow[b]{2}{*}{ Study } & \multirow{2}{*}{$\begin{array}{l}\text { Number of } \\
\text { aneurysms }\end{array}$} & \multicolumn{3}{|c|}{ Initial } & \multirow{2}{*}{$\begin{array}{l}\text { Follow up } \\
\text { months }\end{array}$} & \multicolumn{3}{|c|}{ Follow-up } \\
\hline & & $\begin{array}{c}\text { RG1 } \\
\%\end{array}$ & $\begin{array}{c}\text { RG2 } \\
\%\end{array}$ & $\begin{array}{c}\text { RG3 } \\
\%\end{array}$ & & $\begin{array}{c}\text { RG1 } \\
\%\end{array}$ & $\begin{array}{c}\text { RG2 } \\
\%\end{array}$ & $\begin{array}{c}\text { RG3 } \\
\%\end{array}$ \\
\hline $\begin{array}{c}\text { Brilstra et al. } \\
1999[10]\end{array}$ & 201 & 61 & 26 & 13 & NA & NA & NA & NA \\
\hline $\begin{array}{c}\text { Raymond \& Roy } \\
1997 \text { [17] }\end{array}$ & 75 & 40 & 37 & 23 & 6 & 46 & 42 & 12 \\
\hline $\begin{array}{c}\text { Kuether et al. } \\
1998 \text { [18] }\end{array}$ & 74 & 40 & 52 & 8 & 26 & 41 & 46 & 13 \\
\hline $\begin{array}{c}\text { Byrne et al. } 1999 \\
\text { [12] }\end{array}$ & 317 & NA & NA & NA & 22 & 64 & 34 & 2 \\
\hline $\begin{array}{c}\text { Vanninen et al. } \\
1999 \text { [19] }\end{array}$ & 52 & 50 & 35 & 15 & 3 & 67 & 28 & 5 \\
\hline $\begin{array}{c}\text { Koivisto et al. } \\
2000[20]\end{array}$ & 52 & 50 & 35 & 15 & 12 & 77 & 19 & 4 \\
\hline $\mathrm{Ng}$ et al. 2002 [21] & 136 & 46 & 16 & 38 & NA & NA & NA & NA \\
\hline $\begin{array}{l}\text { Friedman et al. } \\
\quad 2003[22]\end{array}$ & 83 & 33 & 63 & 5 & 19 & 35 & 61 & 3 \\
\hline $\begin{array}{l}\text { Murayama et al. } \\
\quad 2003 \text { [11] }\end{array}$ & 818 & 55 & 35 & 10 & NA & NA & NA & NA \\
\hline $\begin{array}{c}\text { Sluzewski et al. } \\
\quad 2003 \text { [23] }\end{array}$ & 160 & 71 & 22 & 8 & 6 & 59 & 25 & 16 \\
\hline $\begin{array}{c}\text { Henkes et al. } \\
2004 \text { [24] }\end{array}$ & 1811 & 66 & 21 & 13 & NA & NA & NA & NA \\
\hline $\begin{array}{c}\text { Cronqvist et al. } \\
2005 \text { [25] }\end{array}$ & 46 & 37 & 50 & 13 & NA & NA & NA & NA \\
\hline $\begin{array}{l}\text { Molyneux et al. } \\
2005[26]\end{array}$ & 881 & NA & NA & NA & NA & 66 & 26 & 8 \\
\hline $\begin{array}{c}\text { Norbäck et al. } \\
2005 \text { [27] }\end{array}$ & 239 & 53 & 21 & 26 & NA & NA & NA & NA \\
\hline $\begin{array}{c}\text { Geyik et al. } 2010 \\
\text { [28] }\end{array}$ & 80 & 71 & 28 & 1 & 10.5 & 86 & 8 & 6 \\
\hline
\end{tabular}




\begin{tabular}{|c|c|c|c|c|c|c|c|c|}
\hline \multicolumn{9}{|l|}{ Continued } \\
\hline $\begin{array}{l}\text { Maldonado et al. } \\
\quad 2010 \text { [29] }\end{array}$ & 76 & 31 & 26 & 42 & 16.4 & 65 & 13 & 13 \\
\hline Yue, $2011[30]$ & 80 & 76 & 10 & 14 & NA & NA & NA & NA \\
\hline $\begin{array}{l}\text { Nanda et al. } \\
2013[31]\end{array}$ & 66 & 72 & NA & NA & NA & NA & NA & NA \\
\hline Liu et al. 2017 [32] & 113 & 26 & 61 & 13 & NA & NA & NA & NA \\
\hline $\begin{array}{c}\text { Adeeb et al. } \\
2017 \text { [9] }\end{array}$ & 74 & 53 & 23 & 24 & 15 & 70 & 20 & 9 \\
\hline Our study & 76 & 59.2 & 26.3 & 14.5 & 14 & 72.4 & 17.1 & 10.5 \\
\hline
\end{tabular}

These results obtained (complete occlusion initially in 59.2\% of the aneurysms) are comparable to the range of the published series [9] [10] [11] and the results obtained (complete occlusion at 14 months follow up in $72.4 \%$ of the aneurysms) are comparable to the range of the published series $(70 \%$ at 15 months FU) [9]. In terms of neck remnant (RG2), the results of the present study (26.3\% initially and $17.1 \%$ in follow-up) are in the range of the other published series (10\%-63\% initially and $8 \%-61 \%$ in follow-up). In terms of incomplete occlusions (RG3), the results of the present study (14.5\% initially and $10.5 \%$ in follow-up) are in the range of the other published series $(1 \%-38 \%$ initially and $2 \%-16 \%$ in follow-up) (Table 4 ).

In the present study, recanalization was present in only $14.5 \%$ of the aneurysms at the latest follow up which is less than most of the literature reports. The reported rates of aneurysm recanalization vary over a wide range from $17 \%$ to 90\% [7] [12] [13] [14] [15].

Variety of factors influence the rate of occlusion and recanalization including aneurysm-specific factors such as size, neck width, dome-to-neck ratio, location and whether the aneurysm is ruptured or unruptured, and treatment-related factors such as the treatment modality, packing density, and the initial RG [9] [15]. Analysis of these factors showed that the aneurysm size and the neck width were the statistically significant factors affecting the initial RG $(P=0.0005,0.001$ respectively), final $R G(P=0.015,0.012$ respectively), and recanalization rate ( $P$ $=0.012,0.01$ respectively). There was no statistically significant difference regarding the other factors. This is in congruence with the literatures reporting the aneurysm size and neck width as the main factors influencing the occlusion and recurrence. Smaller aneurysm and neck size were predictors of complete occlusion and non-recanalization [9] [15] [16].

The major limitation of our study was the follow up interval. Our follow up interval was 12 months; longer intervals may be more conclusive.

\section{Conclusion}

Endovascular treatment of intracranial aneurysms at bifurcation sites is safe and effective. Stent assisted coiling (SAC) has enabled us to offer a safe and effective 
endovascular treatment for bifurcation aneurysms by preventing coils herniation. Smaller aneurysm size and neck size are indicators of complete occlusion and lower recanalization rate.

\section{Conflicts of Interest}

The authors declare no conflicts of interest regarding the publication of this paper.

\section{References}

[1] Alfano, J.M., Kolega, J., Natarajan, S.K., Xiang, J., Paluch, R.A., Levy, E.I., Siddiqui. A.H. and Meng, H. (2013) Intracranial Aneurysms Occur More Frequently at Bifurcation Sites That Typically Experience Higher Hemodynamic Stresses. Neurosurgery, 73, 497-505. https://doi.org/10.1227/NEU.0000000000000016

[2] Pierot, L. and Wakhloo, A.K. (2013) Endovascular Treatment of Intracranial Aneurysms: Current Status. Stroke, 44, 2046-2054. https://doi.org/10.1161/STROKEAHA.113.000733

[3] Molyneux, A. and Kerr, R. (2002) International Subarachnoid Aneurysm Trial (ISAT) of Neurosurgical Clipping versus Endovascular Coiling in 2143 Patients with Ruptured Intracranial Aneurysms: A Randomized Trial. Journal of Stroke and Cerebrovascular Diseases, 11, 304-314. https://doi.org/10.1053/jscd.2002.130390

[4] Piotin, M. and Blanc, R. (2014) Balloons and Stents in the Endovascular Treatment of Cerebral Aneurysms: Vascular Anatomy Remodeled. Frontiers in Neurology, 5, 41. https://doi.org/10.3389/fneur.2014.00041

[5] Rooij, W.J. and Sluzewski, M. (2009) Opinion: Imaging Follow-Up after Coiling of Intracranial Aneurysms. American Journal of Neuroradiology, 30, 1646-168. https://doi.org/10.3174/ajnr.A1673

[6] Raymond, J., Guilbert, F., Weill, A., Georganos, S.A., Juravsky, L., Lambert, A., Lamoureux, J., Chagnon, M. and Roy, D. (2003) Long-Term Angiographic Recurrences after Selective Endovascular Treatment of Aneurysms with Detachable Coils. Stroke, 34, 1398-1403. https://doi.org/10.1161/01.STR.0000073841.88563.E9

[7] Ries, T., Siemonsen, S., Thomalla, G., et al. (2007) Long-Term Follow-Up of Cerebral Aneurysms after Endovascular Therapy Prediction and Outcome of Retreatment. American Journal of Neuroradiology, 28, 1755-1761. https://doi.org/10.3174/ajnr.A0649

[8] Pierot, L. and Biondi, A. (2016) Endovascular Techniques for the Management of Wide-Neck Intracranial Bifurcation Aneurysms: A Critical Review of the Literature. Journal of Neuroradiology, 43, 167-175. https://doi.org/10.1016/j.neurad.2016.02.001

[9] Adeeb, N., Griessenauer, C., Patel, A., Foreman, P., Baccin, C., Moore, J., Gupta, R., Alturki, A., Harrigan, M., Ogilvy, C. and Thomas, A. (2017) The Use of Single Stent-Assisted Coiling in Treatment of Bifurcation Aneurysms: A Multicenter Cohort Study with Proposal of a Scoring System to Predict Complete Occlusion. Neurosurgery, 82, 710-718. https://doi.org/10.1093/neuros/nyx310

[10] Brilstra, E.H., Rinkel, G.J., van der Graaf, Y., van Rooij, W.J. and Algra, A. (1999) Treatment of Intracranial Aneurysms by Embolization with Coils: A Systematic Review. Stroke, 30, 470-476. https://doi.org/10.1161/01.STR.30.2.470

[11] Murayama, Y., Tateshima, S., Gonzalez, N.R. and Vinuela, F. (2003) Matrix and 
Bioabsorbable Polymeric Coils Accelerate Healing Intracranial Aneurysms: Long-Term Experimental Study. Stroke, 34, 2031-2037. https://doi.org/10.1161/01.STR.0000083394.33633.C2

[12] Byrne, J.V., Sohn, M.J., Molyneux, A.J. and Chir, B. (1999) Five-Year Experience in Using Coil Embolization for Ruptured Intracranial Aneurysms: Outcomes and Incidence of Late Rebleeding. Journal of Neurosurgery, 90, 656-663. https://doi.org/10.3171/jns.1999.90.4.0656

[13] Raymond, J., Roy, D., Leblanc, P., Roorda, S., Janicki, C., Normandeau, L., Morel, F., Gevry, G., Bahary, J.P., Chagnon, M., Guilbert, F. and Weill, A. (2003) Endovascular Treatment of Intracranial Aneurysms with Radioactive Coils: Initial Clinical Experience. Stroke, 34, 2801-2806. https://doi.org/10.1161/01.STR.0000098651.14384.AB

[14] Nguyen, T., Hoh, B., Amin-Hanjani, S., Pryor, J. and Ogilvy, C. (2007) Comparison of Ruptured vs Unruptured Aneurysms in Recanalization after Coil Embolization. Surgical Neurology, 68, 19-23. https://doi.org/10.1016/j.surneu.2006.10.021

[15] Ogilvy, C., Chua, M., Fusco, M., Reddy, A. and Thomas, A. (2015) Stratification of Recanalization for Patients with Endovascular Treatment of Intracranial Aneurysms. Neurosurgery, 76, 390-395. https://doi.org/10.1227/NEU.0000000000000651

[16] Tan, I., Agid, R. and Willinsky, R. (2011) Recanalization Rates after Endovascular Coil Embolization in a Cohort of Matched Ruptured and Unruptured Cerebral Aneurysms. Interventional Neuroradiology, 17, 27-35. https://doi.org/10.1177/159101991101700106

[17] Raymond, J. and Roy, D. (1997) Safety and Efficacy of Endovascular Treatment of Acutely Ruptured Aneurysms. Neurosurgery, 41, 1235-1246. https://doi.org/10.1097/00006123-199712000-00002

[18] Kuether, T.A., Nesbit, G.M. and Barnwell, S.L. (1998) Clinical and Angiographic Outcomes, with Treatment Data, for Patients with Cerebral Aneurysms Treated with Guglielmi Detachable Coils: A Single Center Experience. Neurosurgery, 43, 1016-1025. https://doi.org/10.1097/00006123-199811000-00007

[19] Vanninen, R., Koivisto, T., Saari, T., Hernesniemi, J. and Vapalahti, M. (1999) Ruptured Intracranial Aneurysms: Asute Endovascular Treatment with Electrolytically Detachable Coils-A Prospective Randomized Study. Radiology, 211, 325-336. https://doi.org/10.1148/radiology.211.2.r99ap06325

[20] Koivisto, T., Vanninen, R., Hurskainen, H., Saari, T., Hernesniemi, J. and Vapalahti, M. (2000) Outcomes of Early Endovascular versus Surgical Treatment of Ruptured Cerebral Aneurysms. A Prospective Randomized Study. Stroke, 31, 2369-2377. https://doi.org/10.1161/01.STR.31.10.2369

[21] Ng, P., Khangure, M.S., Phatouros, C.C., Bynevelt, M., ApSimon, H. and McAuliffe W. (2002) Endovascular Treatment of Intracranial Aneurysms with Guglielmi Detachable Coils: Analysis of Midterm Angiographic and Clinical Results. Stroke, 33, 210-217. https://doi.org/10.1161/hs0102.100486

[22] Friedman, J.A., Nichols, D.A., Meyer, F.B., Pichelmann, M.A., McIver, J.I., Toussaint, L.G., Axley, P.L. and Brown Jr., R.D. (2003) Guglielmi Detachable Coil Treatment of Ruptured Saccular Cerebral Aneurysms: Retrospective Review of a 10-Year Single-Center Experience. AJNR, 24, 526-533.

[23] Sluzewski, M., Menovsky, T., van Rooij, W.J. and Wijnalda, D. (2003) Coiling of Very Large or Giant Cerebral Aneurysms: Long-Term Clinical and Serial Angiographic Results. American Journal of Neuroradiology, 24, 257-262.

[24] Henkes, H., Kirsch, M., Mariushi, W., Miloslavski, E., Brew, S. and Kuhne, D. 
(2004) Coil Treatment of a Fusiform Upper Basilar Trunk Aneurysm with a Combination of "Kissing" Neuroform Stents, TriSpan-, 3D- and Fibered Coils, and Permanent Implantation of the Microguidewires. Neuroradiology, 46, 464-468. https://doi.org/10.1007/s00234-004-1192-4

[25] Cronqvist, M., Wirestam, R., Ramgren, B., Brandt, L., Nilsson, O., Säveland, H., Holtås, S. and Larsson, E.M. (2005) Diffusion and Perfusion MRI in Patients with Ruptured and Unruptured Intracranial Aneurysms Treated by Endovascular Coiling: Complications, Procedural Results, MR Findings and Clinical Outcome. Neuroradiology, 47, 855-873. https://doi.org/10.1007/s00234-005-1408-2

[26] Molyneux, A., Kerr, R.S.C., Yu, L.M., Clarke, M., Sneade, M., Yarnold, J.A. and Sandercrock, P., International Subarachnoid Aneurysm Trial (ISAT) Collaborative Group (2005) International Subarachnoid Aneurysm Trial (ISAT) of Neurosurgical Clipping versus Endovascular Coiling in 2143 Patients with Ruptured Intracranial Aneurysms: A Randomized Comparison of Effects on Survival, Dependency, Seizures, Rebleeding, Subgroups, and Aneurysm Occlusion. The Lancet, 366, 809-817. https://doi.org/10.1016/S0140-6736(05)67214-5

[27] Norbäck, O., Gal, G., Johansson, M., Solander, S., Tovi, M., Persson, L., Ronne-Engström, E. and Enblad, P. (2005) The Establishment of Endovascular Aneurysm Coiling at a Neurovascular Unit: Report of Experience during Early Years. Neuroradiology, 47, 144-152. https://doi.org/10.1007/s00234-004-1300-5

[28] Geyik, S., Ertugrul, O., Yavuz, K., Geyik, P., Saatci, I. and Cekirge, H.S. (2010) Comparison of Bioactive Coils and Bare Platinum Coils for Treatment of Intracranial Aneurysms: A Matched-Pair Analysis. Journal of Neurosurgery, 112, 709-713. https://doi.org/10.3171/2009.8.JNS081372

[29] Maldonado, I., Machi, P., Costalat, V., Mura, T. and Bonafé, A. (2010) Neuroform Stent-Assisted Coiling of Unruptured Intracranial Aneurysms: Short- and Midterm Results from a Single-Center Experience with 68 Patients. American Journal of Neuroradiology, 32, 131-136. https://doi.org/10.3174/ajnr.A2245

[30] Yue, W. (2011) Endovascular Treatment of Unruptured Intracranial Aneurysms. Interventional Neuroradiology, 17, 420-424.

https://doi.org/10.1177/159101991101700404

[31] Nanda, A., Sharma, M., Sonig, A., Ambekar, S., Brown, B., Cuellar-Saenz, H. and Madhugiri, V. (2013) Unruptured Intracranial Aneurysms: Comparison of Perioperative Complications, Discharge Disposition, Outcome, and Effect of Calcification, between Clipping and Coiling: A Single Institution Experience. Neurology India, 61, 270. https://doi.org/10.4103/0028-3886.115067

[32] Liu, Y., Wang, F., Fu, X., Liu, Y., Zhang, G. and Xu, K. (2017) Clinical and Angiographic Outcomes Following Endovascular Treatment of Very Small $(3 \mathrm{~mm}$ or Smaller) Intracranial Aneurysm. Medicine, 96, e7457. https://doi.org/10.1097/MD.0000000000007457. 